\title{
STATUS GIZI DAN STATUS KESEHATAN SUKU BADUY
}

\author{
(Nutrition and Health Status of Baduy Tribe) \\ Faisal Anwar ${ }^{1 *}$ dan Hadi Riyadi ${ }^{2}$ \\ ${ }^{1 *}$ Alamat Korespondensi: Departemen Gizi Masyarakat, Fakultas Ekologi Manusia, Institut Pertanian \\ Bogor, Bogor 16680. Telp: 0251-8621258; Fax: 0251-8622276; \\ Email: faisalanwar_gmipb@yahoo.com \\ 2 Departemen Gizi Masyarakat, Fakultas Ekologi Manusia, Institut Pertanian Bogor, Bogor 16680
}

\begin{abstract}
ABST RACT
The objectives of the study were: (1) To analyze the socio-economic and demographic characteristics of Baduy people; (2) To analyze the health status and nutritional status of Baduy people and its influential factors. This research is an explorative and descriptive study on the socio-cultural aspects of food system. The data were collected through a direct interview and discussion with respondents as well as a direct observation at the location of respondents. A sample size of 338 households was drawn from the population. To obtain the data on the cultural aspects, history and socio aspect of food, in-depth interviews was conducted with 19 key persons. The study was last for 12 months. In Outer Baduy, the factors significantly related to nutritional status are age, number of household size, income, nutritional knowledge, and wife's ability to read. In Moslem Baduy, only age and income are related to the nutritional status of children. In Moslem Baduy and the Outer Baduy, the correlation between age and W/A or W/H is similar: namely, the higher the age, the lower would the Z-score for the W/A or $\mathrm{W} / \mathrm{H}$. The income is significantly correlated to the child nutritional status according to Zscore for W/A with a high correlation coefficient, that is, 0.61 . This means that the higher the income, the higher would be the Z-score value for the W/A. The distribution of adults according to BMI classification in Outer Baduy it shows that $12.7 \%$ husbands and $17.6 \%$ wives are thin (wasted), while the overweight prevalence of the husbands is $2.4 \%$ and the wives $8.6 \%$ This shows that Baduy women suffer from double nutrition problems (double burden). When the survey was carried out, $2.7 \%$ women were pregnant and still breastfeeding, the rest was neither pregnant nor breastfeeding.
\end{abstract}

Key words: health status, child nutritional status and body mass index

\section{PENDAHULUAN}

Status gizi merupakan kondisi kesehatan tubuh seseorang atau sekelompok orang yang diakibatkan oleh konsumsi, penyerapan (absorbsi), dan penggunaan (utilisasi) zat gizi makanan. Dengan menilai status gizi seseorang atau sekelompok orang, maka dapat diketahui baik buruk status gizinya (Riyadi, 1995). Menurut Tarwotjo dan Soekirman (1987) status gizi merupakan tanda-tanda atau penampilan seseorang akibat keseimbangan antara pemasukan dan pengeluaran gizi yang berasal dari pangan yang dikonsumsi. Dapat disebutkan pula bahwa status gizi seseorang pada dasarnya merupakan gambaran kesehatan sebagai refleksi dari konsumsi pangan dan penggunaannya oleh tubuh.

Pemantauan status gizi anak lebih tepat jika menggunakan baku WHO-NHCS dan dihitung berdasarkan skor simpangan baku (Z- skor). Keuntungan penggunaan Z-skor adalah hasil hitungan telah dibakukan menurut simpangan baku, sehingga dapat dibandingkan untuk setiap kategori umur dan indeks antropometri. Penentuan prevalensi malnutrisi berdasarkan nilai Z-skor lebih tepat dibandingkan cara persen terhadap median (Gibson, 1993).

Terjadinya masalah gizi tidak hanya disebabkan oleh asupan gizi yang kurang, tetapi juga dipengaruhi oleh penyakit infeksi. Anak yang mendapatkan makanan yang cukup, tetapi sering diserang diare, atau penyakit ispa dan demam, akhirnya dapat juga menderita kurang gizi. Pada anak yang mendapatkan makanan yang tidak cukup, maka daya tahan tubuhnya melemah. Dalam keadaan demikian anak tersebut mudah diserang penyakit infeksi yang dapat mengurangi nafsu makannya dan menyebabkan kurang gizi. 
J enis penyakit yang masih sering dialami oleh masyarakat Baduy secara umum adalah penyakit kulit dan penyakit infeksi. Penyakit yang masih mewabah di kalangan orang Baduy adalah penyakit frambosia. Frambosia adalah sejenis penyakit kulit menular dimana permukaan kulit berbentuk seperti kembang kol. Nama lokal penyakit ini adalah patek atau butul. Penyakit ini sebetulnya dapat menimbulkan kematian. Cara penyembuhan adalah dengan dilakukan penyuntikan benzalin penicillin. Kasus yang paling baru terjadi pada tahun 1970an atau pada awal mantri kesehatan bertugas di Kanekes.

Tujuan yang ingin dicapai dalam penelitian ini adalah (1) Menganalisis karakteristik sosial-ekonomi dan demografi masyarakat Baduy dan (2) Menganalisis status gizi dan status kesehatan masyarakat Baduy dan faktor-faktor yang mempengaruhinya.

\section{METODE}

\section{Desain, Tempat dan Waktu}

Penelitian ini adalah studi deskriptif dan eksploratif terhadap aspek sosial-budaya sistem pangan. Penelitian dilakukan pada masyarakat Baduy yang masih memegang kuat tradisi dari nenek moyang mereka. Masyarakat Baduy ini tinggal di Desa Kanekes, Kecamatan Leuwidamar, Kabupaten Lebak, Provinsi Banten. Penelitian ini dilakukan selama 12 bulan pada tahun 2008.

\section{J umlah dan Cara Penarikan Sampel}

Ukuran sampel sebanyak 338 rumah tangga diambil dari jumlah penduduk, dengan alokasi sampel sebanyak 303 untuk Baduy Luar, 10 untuk Baduy Dalam dan 25 untuk Baduy Muslim. Untuk mendapatkan data aspek budaya, sejarah dan aspek sosial pangan, wawancara mendalam dilakukan terhadap 19 orang tokoh kunci. Sampel rumah tangga diperoleh dari 13 kampung di Baduy Luar, Baduy Dalam, dan Baduy Muslim. Tokoh kunci diperoleh dari beberapa kampung di Baduy Luar, Baduy DaIam (Kampung Cibeo), Baduy Muslim (Kampung Cikakal Girang), dan tokoh kunci yang tinggal di sekitar Desa Kanekes. Untuk memilih sampel rumah tangga, dibuat kerangka sampling dengan 13 kampung. Terdapat sekitar 12500 orang atau 2500 rumah tangga di Desa Kanekes. Kemudian, sampel rumah tangga diambil secara acak dari kerangka sampling di setiap kampung (sampel).

\section{J enis dan Cara Pengumpulan Data}

Data yang dikumpulkan meliputi data pri mer dan data sekunder. Data yang dibutuhkan untuk memenuhi tujuan penelitian dikumpulkan dengan berbagai cara. Data primer dikumpulkan melalui wawancara langsung dan diskusi dengan responden serta pengamatan langsung di lokasi responden. Responden untuk data primer adalah istri, suami, dan tokoh masyarakat, yaitu kepada desa, pimpinan agama, tokoh masyarakat tradisional, dan lainnya. Data sekunder dikumpulkan dengan pencarian data di desa, kecamatan, dan kantor pemerintah daerah. Instrumen penelitian yang dikembangkan adalah kuesioner.

\section{Pengolahan dan Analisis Data}

Proses dan pengolahan data termasuk memeriksa kelengkapan data, pengkodean, mengatur struktur file, entry data dan editing. Pada penelitian ini file dimasukkan ke dalam Microsoft Excel. Untuk menjawab tuj uan penelitian, penjelasan mengenai sosial budaya sistem pangan dan gizi dibuat. Hal ini dilakukan melalui perhitungan statistika dasar, termasuk mean, standar deviasi, nilai minimum dan maksimum seluruh variabel kontinyu dan perhitungan proporsional untuk seluruh kategori variabel kuantitatif. Hasil perhitungan disaj ikan dalam bentuk tabel agar karakteristik sosial budaya sistem pangan dan gizi masyarakat Baduy dapat dilihat dengan jelas. Perhitungan nilai statistika dasar dan proporsi berdasarkan program Statistical Analysis Sistem (SAS). Semua data kualitatif dianalisis secara deskriptif.

\section{HASIL DAN PEMBAHASAN}

\section{Keadaan Sosio Ekonomi dan Demografi}

\section{Pendidikan}

Baduy Muslim jauh lebih banyak yang mempunyai kemampuan baca dan tulis dibanding Baduy Luar. Sejumlah $92 \%$ suami atau istri mempunyai kemampuan baca dan tulis (Tabel 1). Hal ini menunjukkan memang Baduy Muslim jauh lebih terbuka dan lebih maju dibanding Baduy Luar dan juga Baduy Dalam. Orang Baduy baik Baduy Dalam maupun Luar dilarang sekolah oleh adat. Bagi orang Baduy orang pintar tidak dibutuhkan, yang penting adalah orang yang ngarti (mengerti), sehingga tidak ditipu dan dibodohi oleh orang lain.

\section{Mata Pencaharian}

Tabel 2 menunjukkan bahwa sebagian besar orang Baduy Luar mempunyai pekerjaan 
sebagai petani (98.6\% untuk suami dan $90.7 \%$ untuk istri). Pekerjaan lainnya adalah berdagang dan bertenun (terutama untuk istri), karena bisa dilakukan di rumah sambil mengasuh anak. Tidak banyak jenis pekerjaan yang dilakukan oleh orang Baduy karena hidupnya masih sepenuhnya mengandalkan sumberdaya alam. Demikian juga untuk Baduy Dalam yang bahkan $100 \%$ pekerjaannya adalah sebagai petani karena memang domisilinya jauh di daerah pedalaman sehingga tidak ada pilihan pekerjaan, jika ada yang berdagang itupun hanya satu atau dua orang dan selalu dilakukan oleh pendatang. Untuk Baduy Muslim lebih banyak variasi jenis pekerjaannya yaitu selain sebagai petani juga ada yang bekerja sebagai guru, buruh atau ibu rumah tangga. Secara adat memang Baduy Muslim sudah dianggap bukan orang Baduy sehingga Baduy Muslim sudah seperti perkampungan lainnya di Indonesia.

Mata pencaharian orang Baduy adalah berladang dengan menanam padi. Padi hanya boleh ditanam di lahan ladang kering tanpa pengairan yang disebut huma. Padi tidak boleh dijual dan harus disimpan dengan baik untuk keperluan sehari-hari. Selain ngahuma, orang Baduy juga bertani untuk memperoleh bahan makanan tambahan. J enis tanaman yang ditanam adalah buah-buahan seperti durian, pisang, kelapa dan jagung serta umbi-umbian se- perti singkong, talas dan ubi. Bibit mereka peroleh secara turun temurun yaitu dari hasil panen sebelumnya yang ditanam kembali.

\section{Pendapatan dan Pengeluaran}

Pada Tabel 3 dapat diketahui bahwa pendapatan rata-rata responden terbesar diperoleh oleh masyarakat Baduy Muslim yaitu sebesar Rp $199468 \pm$ Rp 248 600, begitu juga dengan pengeluarannya yaitu Rp $227265 \pm$ Rp 107 255. Lebih dari separuh pengeluaran (74.2\%) digunakan untuk pangan (Rp $168179 \pm$ Rp 84 534) dan sebesar 25.8\% digunakan untuk non pangan (Rp $168179 \pm$ Rp 84 534). Pengeluaran rumah tangga orang Baduy (baik untuk Baduy Luar, Baduy Dalam maupun Baduy Muslim) selalu lebih besar dibandingkan dengan pendapatannya. Untuk memenuhi kebutuhan sehari-harinya orang Baduy sering mengandalkan sumberdaya alam di sekitarnya. Ciri khas masyarakat golongan ekonomi lemah adalah sebagian besar pengeluarannya untuk pangan sedangkan pengeluaran lain dianggap pengeluaran sekunder yang tidak terlalu diutamakan.

Jika kita kaji lebih jauh pada Tabel 4 dapat diketahui bahwa pengeluaran pangan yang terbesar orang Baduy dialokasikan membeli lauk pauk dan makanan jajanan. Hal ini sangat masuk akal karena sumberdaya alam di

Tabel 1. Sebaran Suami/Istri yang Bisa Membaca dan Menulis di Baduy Luar, Baduy Dalam, dan Baduy Muslim

\begin{tabular}{|c|c|c|c|c|c|c|c|c|c|c|c|c|}
\hline \multirow{3}{*}{ Kemampuan } & \multicolumn{4}{|c|}{ Baduy Luar } & \multicolumn{4}{|c|}{ Baduy Dalam } & \multicolumn{4}{|c|}{ Baduy Muslim } \\
\hline & \multicolumn{2}{|c|}{ Suami } & \multicolumn{2}{|c|}{ Istri } & \multicolumn{2}{|c|}{ Suami } & \multicolumn{2}{|c|}{ Istri } & \multicolumn{2}{|c|}{ Suami } & \multicolumn{2}{|c|}{ Istri } \\
\hline & $\mathbf{n}$ & $\%$ & $\mathbf{n}$ & $\%$ & $n$ & $\%$ & $\mathbf{n}$ & $\%$ & $\mathbf{n}$ & $\%$ & $n$ & $\%$ \\
\hline Membaca & 93 & 32.7 & 44 & 14.9 & 1 & 10 & 0 & 0.0 & 23 & 92 & 23 & 92 \\
\hline Menulis & 85 & 29.9 & 39 & 13.2 & 1 & 10 & 0 & 0.0 & 23 & 92 & 23 & 92 \\
\hline
\end{tabular}

Tabel 2. Sebaran Suami/Istri di Baduy Luar, Baduy Dalam, dan Baduy Muslim menurut Pekerjaan

\begin{tabular}{|c|c|c|c|c|c|c|c|c|c|c|c|c|}
\hline \multirow{3}{*}{ Pekerjaan } & \multicolumn{4}{|c|}{ Baduy Luar } & \multicolumn{4}{|c|}{ Baduy Dalam } & \multicolumn{4}{|c|}{ Baduy Muslim } \\
\hline & \multicolumn{2}{|c|}{ Suami } & \multicolumn{2}{|c|}{ Istri } & \multicolumn{2}{|c|}{ Suami } & \multicolumn{2}{|c|}{ Istri } & \multicolumn{2}{|c|}{ Suami } & \multicolumn{2}{|c|}{ Istri } \\
\hline & $\mathbf{n}$ & $\%$ & 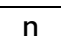 & $\%$ & $\mathbf{n}$ & $\%$ & $n$ & $\%$ & $\mathbf{n}$ & $\%$ & $\mathbf{n}$ & $\%$ \\
\hline Petani & 275 & 98.6 & 175 & 90.7 & 10 & 100 & 2 & 20 & 18 & 72 & 0 & 0.0 \\
\hline Pedagang & 1 & 0.4 & 6 & 3.1 & 0 & 0.0 & 0 & 0.0 & 1 & 4 & 0 & 0.0 \\
\hline Bertenun & 1 & 0.4 & 12 & 6.2 & 0 & 0.0 & 0 & 0.0 & 0 & 0.0 & 0 & 0.0 \\
\hline Lainnya & 2 & 0.8 & 0 & 0.0 & 0 & 0.0 & 0 & 0.0 & 6 & 24 & 17 & 100 \\
\hline
\end{tabular}

Tabel 3. Statistik Pendapatan dan Pengeluaran (rp/kapita/bulan) di Baduy Luar Baduy Dalam, dan Baduy Muslim

\begin{tabular}{|c|c|c|c|c|c|c|}
\hline \multirow{2}{*}{ Statistik } & \multicolumn{2}{|l|}{ Baduy Luar } & \multicolumn{2}{|c|}{ Baduy Dalam } & \multicolumn{2}{|c|}{ Baduy Muslim } \\
\hline & mean \pm sd $(r p)$ & $\%$ & mean \pm sd (rp) & $\%$ & mean $\pm \mathrm{sd}(\mathrm{rp})$ & $\%$ \\
\hline Pendapatan & $139094 \pm 136042$ & & $88480 \pm 47561$ & & $199468 \pm$ & \\
\hline Pengeluaran: & $154377 \pm 120984$ & 100.0 & $109104 \pm 86706$ & 100.0 & $227265 \pm 107255$ & 100.0 \\
\hline a. Pangan & $95078 \pm 85523$ & 61.6 & $106687 \pm 83923$ & 98.0 & $168179 \pm 84534$ & 74.2 \\
\hline b. Non Pangan & $59299 \pm 49527$ & 38.4 & $2417 \pm 5144$ & 2.0 & $59086 \pm 39359$ & 25.8 \\
\hline
\end{tabular}


Tabel 4. Statistik J enis-jenis Pengeluaran Pangan dan Non pangan di Baduy Luar, Baduy Dalam, dan Baduy Muslim Per Kapita Per Bulan

\begin{tabular}{lcccccc}
\hline \multirow{2}{*}{ J enis Pengeluaran } & \multicolumn{2}{c}{ Baduy Luar } & \multicolumn{2}{c}{ Baduy Dalam } & \multicolumn{2}{c}{ Baduy Muslim } \\
\cline { 2 - 7 } & Rp & $\%$ & Rp & Rp & $\%$ \\
\hline Pangan & 24699 & 26.0 & 20167 & 18.9 & 31943 & 19.0 \\
a. Lauk Pauk & 5845 & 6.1 & 1275 & 1.2 & 6246 & 3.7 \\
b. Sayuran & 2278 & 2.4 & 17 & 0.0 & 1848 & 1.1 \\
c. Buah & 28006 & 29.5 & 12268 & 11.5 & 35007 & 20.8 \\
d. Jajanan & 35761 & 37.6 & 72961 & 68.4 & 93135 & 55.4 \\
e. Lainnya & & & & & & \\
NonPangan & 6215 & 10.5 & 100 & 4.1 & 6416 & 10.9 \\
a. Kesehatan & 5465 & 9.2 & 667 & 27.6 & 5306 & 9.0 \\
b. Pakaian & 6720 & 11.3 & 0 & 0.0 & 1333 & 2.3 \\
c. Bahan Bakar & 31352 & 52.9 & 0 & 0.0 & 34187 & 57.9 \\
d. Rokok & 2035 & 3.4 & 0 & 0.0 & 200 & 0.3 \\
e. Sumbangan & 7513 & 12.7 & 1650 & 68.3 & 11643 & 19.7 \\
f. Lainnya & & & & & & \\
\hline
\end{tabular}

Baduy tidak banyak menyediakan bahan pangan yang dapat diolah sebagai lauk pauk nabati apalagi untuk lauk pauk hewani. Keadaan ini memang akan menyebabkan orang Baduy memenuhi kebutuhan lauknya sangat tergantung suplai dari luar. Demikian juga untuk makanan jajanan, orang Baduy banyak yang tidak mempunyai ketrampilan untuk membuat makanan jajanan, sehingga sepenuhnya harus membeli dari luar. Untuk kebutuhan non pangan, pengeluaran terbesarnya adalah untuk membeli rokok (Baduy Luar $52.9 \%$ dan Baduy Muslim 57.9\%).

\section{Kepemilikan Aset Rumah Tangga}

Tabel 5 menunjukkan hampir semua keluarga di Baduy memiliki tungku dari tanah liat untuk keperluan memasaknya dan memilki bale-bale di depan rumahnya yang biasanya digunakan untuk menerima tamu atau untuk tempat istirahat. Masyarakat Baduy tidak mempunyai alat-alat elektronik seperti televisi, tape reconder dan lain sebagainya karena secara adat kepemilikan aset-aset yang memerlukan sentuhan teknologi terutama alat elektronik tidak diperbolehkan. J adi peralatan rumah tangga yang ada di masyarakat Baduy Dalam sangat terbatas dan hanya mengandalkan alat-alat dengan bahan alami yang ada di sekitarnya. Jika dibandingkan dengan Baduy Dalam, kondisi
Baduy Muslim sangat kontras, karena hampir semua rumah tangga Baduy Muslim mempunyai tempat tidur $(72.0 \%)$, lemari pakaian $(92.0 \%)$, tungku $(64.0 \%)$, dan bale-bale $(20.0 \%)$. Hal ini karena di Baduy Muslim tidak ada larangan untuk kepemilikan aset apapun.

\section{Perumahan}

Tabel 6 menunjukkan sebagian besar responden di Baduy Luar, Baduy Dalam dan Baduy Muslim telah memiliki rumah sendiri. Hanya sebagian kecil yang masih tinggal bersama orang tuanya. Masyarakat Baduy Dalam mendiami rumah yang lebih luas $\left(59.6 \mathrm{~m}^{2} \pm 18.25 \mathrm{~m}^{2}\right)$ dibandingkan orang Baduy Luar $\left(45 \mathrm{~m}^{2} \pm 15 \mathrm{~m}^{2}\right)$. Hal ini sangat logis karena di pedalaman yang dihuni oleh Baduy Dalam lahannya sangat luas, sedangkan penduduknya masih sangat jarang. Untuk masyarakat Baduy Muslim luas rumahnya $\left(38.10 \mathrm{~m}^{2} \pm 12.42 \mathrm{~m}^{2}\right)$ lebih kecil dibanding Baduy Luar maupun Baduy Dalam. Lebih banyak responden Baduy Muslim yang masih tinggal bersama orang tuanya (24\%) jika dibandingkan masyarakat Baduy Luar maupun Baduy Dalam.

\section{Status Gizi dan Kesehatan}

\section{Status Kesehatan}

Hasil pengamatan terlihat bahwa ratarata balita Baduy Dalam tidak menderita pe-

Tabel 5. Persentase Kepemilikan Aset Rumah Tangga di Baduy Luar, Baduy Dalam, dan Baduy Muslim

\begin{tabular}{|c|c|c|c|c|c|c|}
\hline \multirow{2}{*}{ Aset } & \multicolumn{2}{|c|}{ Baduy Luar } & \multicolumn{2}{|c|}{ Baduy Dalam } & \multicolumn{2}{|c|}{ Baduy Muslim } \\
\hline & $\mathbf{n}$ & $\%$ & $\mathbf{n}$ & $\%$ & $\mathbf{n}$ & $\%$ \\
\hline Tempat Tidur & 49 & 16.2 & 1 & 10.0 & 18 & 72.0 \\
\hline Tungku & 303 & 100.0 & 10 & 100.0 & 16 & 64.0 \\
\hline Bale-bale & 297 & 98.0 & 6 & 60.0 & 5 & 20.0 \\
\hline Emas & 17 & 5.6 & 0 & 0.0 & 0 & 0.0 \\
\hline
\end{tabular}


Tabel 6. Sebaran Rumah Tangga di Baduy Luar, Baduy Dalam dan Baduy Muslim menurut Status dan Ukuran Rumah

\begin{tabular}{lcccccc}
\hline \multirow{2}{*}{ Status/Ukuran } & \multicolumn{2}{c}{ Baduy Luar } & \multicolumn{2}{c}{ Baduy Dalam } & \multicolumn{2}{c}{ Baduy Muslim } \\
\cline { 2 - 7 } & $\mathbf{n}$ & $\%$ & $\mathbf{n}$ & $\%$ & $\mathbf{n}$ & $\%$ \\
\hline Status & 275 & 90.8 & 8 & 80.0 & 19 & 76.0 \\
a. Milik Sendiri & 23 & 7.6 & 2 & 20.0 & 6 & 24.0 \\
b. Orang Tua & 5 & 1.7 & 0 & 0.0 & 0 & 0.0 \\
c. Lainnya & \multicolumn{2}{c}{$45 \pm 15$} & & $59.60 \pm 18.25$ & $38.10 \pm 12.42$ \\
Ukuran rumah $\left(\mathrm{m}^{2}\right)$ & & & & & \\
\hline
\end{tabular}

Tabel 7. Sebaran J umlah Balita di Baduy Luar, Baduy Dalam dan Baduy Muslim menurut J enis Penyakit Kulit yang Diderita

\begin{tabular}{|c|c|c|c|c|c|c|}
\hline \multirow{2}{*}{ J enis Penyakit Kulit } & \multicolumn{2}{|c|}{ Baduy Luar } & \multicolumn{2}{|c|}{ Baduy Dalam } & \multicolumn{2}{|c|}{ Baduy Muslim } \\
\hline & $\mathbf{n}$ & $\%$ & $\mathbf{n}$ & $\%$ & $\mathbf{n}$ & $\%$ \\
\hline Tidak Menderita Sakit Kulit & 74 & 63.2 & 8 & 100.0 & 22 & 88.0 \\
\hline Budug & 24 & 20.9 & 0 & 0.0 & 0 & 0.0 \\
\hline Gatal & 10 & 8.5 & 0 & 0.0 & 3 & 12.0 \\
\hline Bentol & 5 & 4.3 & 0 & 0.0 & 0 & 0.0 \\
\hline Kulit Kemerahan & 3 & 2.6 & 0 & 0.0 & 0 & 0.0 \\
\hline Bisul & 1 & 0.9 & 0 & 0.0 & 0 & 0.0 \\
\hline
\end{tabular}

nyakit kulit (Tabel 7), keadaan ini agak berbeda dengan masyarakat Baduy Luar yang masih banyak menderita berbagai penyakit kulit. Keadaan ini merupakan suatu fenomena yang perlu dikaji lebih lanjut, karena masyarakat Baduy Dalam tidak boleh menggunakan sabun mandi. Berbeda dengan masyarakat Baduy Luar yang sudah mengenal sabun untuk mencuci dan untuk mandi. Kemungkinan lain adalah karena hanya 8 balita atau 8 keluarga Baduy Dalam yang mau diwawancara atau diperiksa, sedangkan untuk Baduy Luar sebanyak 303 keluarga. Balita Baduy Muslim sebagian besar sudah tidak menderita penyakit kulit, hanya sekitar $12 \%$ yang menderita penyakit kulit sejenis gatal-gatal, itu pun disebabkan oleh gigitan seranga. Masyarakat Baduy Muslim sudah mengenal pendidikan, kebersihan dan kesehatan baik secara formal melalui sekolah atau pengajian maupun secara informal dari orang tua atau tokoh masyarakat setempat. Mereka juga sudah menggunakan sabun untuk mencuci dan mandi, dan cara berpakaian juga berbeda dengan masyarakat Baduy Luar maupun Baduy Dalam. Kalau masyarakat Baduy Luar dan Baduy Dalam jarang berganti pakaian, masyarakat Baduy Muslim sudah mengenal kebersihan dan sering menganti pakaian kalau sudah kotor. Keadaan ini yang menyebabkan masyarakat Baduy Muslim sudah jarang terkena penyakit kulit.

J enis penyakit yang ada kaitannya dengan kesehatan lingkungan adalah penyakit diare dan ISPA. Berdasarkan Tabel 8, balita Baduy Luar yang menderita diare dengan frekuensi 1.1 kali dalam dua minggu terakhir de- ngan lama diare rata-rata 5.2 hari adalah 27. 1\% Sementara itu, balita Baduy Luar yang menderita ispa dengan frekunsi 1.4 kali dalam dua minggu terakhir dengan lama ispa diderita selama 4.6 hari adalah sebesar $62.1 \%$ Data mengenai penyakit yang sering diderita oleh masyarakat Baduy Dalam tidak dapat dilihat secara langsung. Sebagian besar keluarga Baduy Dalam khususnya ibu rumah tangga sangat tertutup dan tidak bisa diwawancara. Kalau melihat kondisi perumahan dan lingkungan Baduy Dalam dan Baduy Luar, keadaan lingkungan Baduy Luar sedikit lebih baik. Diduga penyakit ispa dan diare yang diderita masyarakat Baduy Luar akan lebih rendah bila dibandingkan masyarakat Baduy Dalam.

Rata-rata penyakit diare yang diderita oleh masyarakat Baduy Muslim dengan frekuensi satu kali dengan lama menderita 4.6 hari. Sebanyak 20\% dari balita Baduy Muslim pernah menderita diare, sedangkan penyakit ispa yang diderita oleh masyarakat Baduy Muslim ratarata dengan frekuensi satu kali dengan lama menderita 6.6 hari. Sebanyak 50\% balita di Baduy Muslim pernah menderita penyakit ispa. Penyakit ispa lebih disebabkan oleh keadaan udara yang sudah tidak bersih. Pencemaran udara yang terjadi di daerah Banten merupakan penyebab tercemarnya udara di daerah Baduy, sehingga dapat memicu banyaknya penderita ISPA.

Sebesar 25.2\% masyarakat Baduy Luar sudah mengunjungi Puskesmas untuk berobat. Sebagian besar warga masih acuh tidak acuh atau memberikan reaksi dengan istilah Baduy "teu matak" yang berarti tidak ada pengaruh- 
nya bagi mereka. Sebagian kecil masyarakat Baduy Luar sudah mengunjungi bidan, mantri dan dokter kalau menderita sakit. Sebagian besar masyarakat Baduy Dalam tidak mau berobat ke bidan ataupun petugas kesehatan lainnya. Masyarakat Baduy Dalam tetap masih percaya pada dukun dan selalu datang ke dukun kalau mengalami keadaan kurang sehat atau sakit. Alasan mereka mau berobat ke mantri hanya apabila berobat ke dukun tidak kunjung sembuh. Masyarakat Baduy Muslim sudah cukup maju dalam memahami dan melaksanakan konsep kesehatan yang benar. Sebagian besar masyarakat Baduy Muslim sudah datang ke puskesmas kalau menderita sakit. Sebanyak 64\% masyarakat Baduy Muslim datang ke puskesmas kalau mereka sakit. Sebagian lainnya memilih membeli obat langsung ke warung kalau menderita sakit, yaitu sebesar 32\% Masyarakat Baduy Muslim tidak mau berobat ke dukun dan dukun di Baduy Muslim juga tidak ada (Lihat Tabel 9). Selain puskesmas, bidan desa juga merupakan alternatif mereka untuk berobat.
Keadaan ini juga ikut membantu tercapainya masyarakat sehat di Baduy Muslim.

\section{Status Gizi Orang Dewasa Baduy Luar}

Rata-rata umur suami dan isteri masih tergolong muda, masing-masing 36.5 tahun dan 32 tahun (Tabel 10) atau umur suami 4.5 tahun lebih tua dari umur istri. Berat badan suami dan istri masing-masing $51 \mathrm{~kg}$ dan $46 \mathrm{~kg}$, sedangkan tinggi badan $157 \mathrm{~cm}$ dan istri $149 \mathrm{~cm}$. Dengan pola berat badan dan tinggi badan tersebut jelas orang Baduy perperawakan kecil. Kalau dilihat indeks massa tubuh (BMI) suami dan istri rata-ratanya hampir sama, yaitu 21. Berdasarkan BMI rata-rata, orang dewasa Baduy tergolong normal.

Pada Tabel 11 disajikan sebaran orang dewasa menurut klasifikasi BMI. Pada Tabel 11 terlihat bahwa $12.7 \%$ suami dan $17.6 \%$ tergolong kurus (wasted), sedangkan prevalensi overweight pada suami $2.4 \%$ dan isteri $8.6 \%$ Keadaan ini menunjukkan bahwa kaum wanita Baduy Luar menghadapi masalah gizi ganda (double burden).

Tabel 8. Frekuensi (kali) dan Lama (hari) Sakit Balita Dua Minggu Terakhir di Baduy Luar, Baduy Dalam dan Baduy Muslim

\begin{tabular}{lcccc}
\hline \multicolumn{1}{c}{ J enis Penyakit } & Frekuensi (kali) & Lama (hari) & n & $\%$ \\
\hline Baduy Luar & & & & \\
Diare & $1.1 \pm 0.4$ & $5.2 \pm 2.7$ & 29.0 & 27.1 \\
ISPA & $1.4 \pm 0.8$ & $4.6 \pm 2.2$ & 67.0 & 62.1 \\
Baduy Dalam & - & - & - & - \\
Diare & $1.0 \pm 0.0$ & $7.0 \pm 0.0$ & 2 & 100.0 \\
ISPA & & & & 20.0 \\
Baduy Muslim & $1.0 \pm 0.0$ & $4.6 \pm 2.3$ & 5 & 50.2 \\
Diare & $1.1 \pm 0.3$ & $6.6 \pm 4.0$ & 12 & \\
ISPA & & & & \\
\hline
\end{tabular}

Tabel 9. Sebaran Rumah Tangga Baduy Luar menurut Cara Berobat

\begin{tabular}{|c|c|c|c|c|c|c|}
\hline Cara Berobat & \multicolumn{2}{|c|}{ Baduy Luar } & \multicolumn{2}{|c|}{ Baduy Dalam } & \multicolumn{2}{|c|}{ Baduy Muslim } \\
\hline Puskesmas & 27 & 25.2 & 0 & 0.0 & 16 & 64.0 \\
\hline Beli obat di warung & 9 & 8.4 & 0 & 0.0 & 8 & 32.0 \\
\hline Bidan & 6 & 5.6 & 0 & 0.0 & 1 & 4.0 \\
\hline Mantri & 5 & 4.7 & 0 & 0.0 & 0 & 0.0 \\
\hline Dukun & - & - & 5 & 62.5 & 0 & 0.0 \\
\hline Lainnya & 59 & 55.1 & 3 & 37.5 & 0 & 0.0 \\
\hline
\end{tabular}

Tabel 10. Statistik Umur dan Antropometri Suami dan Istri di Baduy Luar

\begin{tabular}{lcc}
\hline Karakteristik & Suami & Istri \\
\hline Umur (tahun) & $36.6 \pm 13.1$ & $32.1 \pm 14.1$ \\
Berat Badan $(\mathrm{kg})$ & $51.1 \pm 6.3$ & $46.4 \pm 8.0$ \\
Tinggi Badan $(\mathrm{cm})$ & $156.9 \pm 7.1$ & $148.9 \pm 19.7$ \\
IMT & $20.8 \pm 2.1$ & $21.2 \pm 3.2$ \\
\hline
\end{tabular}


Tabel 11. Sebaran Suami atau Istri menurut Status Gizi (IMT) di Baduy Luar

\begin{tabular}{lcccc}
\hline \multirow{2}{*}{ BM|* } & \multicolumn{2}{c}{ Suami } & \multicolumn{2}{c}{ Istri } \\
\cline { 2 - 5 } & $\mathbf{n}$ & $\%$ & $\mathbf{n}$ & $\%$ \\
\hline$<18.5$ & 27 & 12.7 & 39 & 17.6 \\
$18.5-25.0$ & 180 & 84.9 & 163 & 73.8 \\
$>25$ & 5 & 2.4 & 19 & 8.6 \\
\hline
\end{tabular}

*KLasifikasi WHO (1995)

\section{Status Gizi Anak Balita Baduy Luar}

Berdasarkan hasil perhitungan Z-skor $\mathrm{BB} / \mathrm{U}$ dan dengan menggunakan titik batas < 2SD sebagai underweight, maka prevalensi underweight pada anak balita adalah $26.4 \%$ (Tabel 12). Prevalensi underweight anak Baduy lebih tinggi daripada prevalensi underweight anak Indonesia hasil Riset Kesehatan Dasar (Riskesdas) 2007, yaitu 18.4\%(Depkes, 2008).

Tabel 12. Persentase Status Gizi Balita di Baduy Luar menurut Kategori Z-score

\begin{tabular}{lccc}
\hline Status Gizi & $\mathbf{Z}$ score $<-\mathbf{2}$ & $\mathbf{- 2}<\mathbf{Z}$ score $<+\mathbf{2}$ & $\mathbf{Z}$ score $>\mathbf{+ 2}$ \\
\hline $\mathrm{BB} / \mathrm{U}$ & 26.4 & 70.8 & 2.8 \\
$\mathrm{~TB} / \mathrm{U}$ & 60.6 & 31.8 & 7.6 \\
$\mathrm{BB} / \mathrm{TB}$ & 16.7 & 68.1 & 15.3 \\
\hline
\end{tabular}

Prevalensi stunted (pendek) secara keseluruhan adalah sebesar $60.6 \%$ Prevalensi ini jauh lebih tinggi daripada prevalensi stunting anak balita di Indonesia hasil Riskesdas 2007, yang hanya sekitar 36.8\% (Depkes, 2008). Artinya kondisi ini mencerminkan tingkat kesejahteraan masyarakat di desa penelitian masih rendah. Berdasarkan hasil perhitungan Z-skor indeks BB/TB dengan kriteria wasted $<-2 \mathrm{SD}$, maka ditemukan prevalensi wasted sebesar 16.7\% (Tabel 12). Prevalensi wasted ini sedikit lebih tinggi dibandingkan dengan prevalensi wasted anak balita di Indonesia hasil Riskesdas 2007, yaitu 13.6\% (Depkes, 2008). Hal yang menarik adalah prevalensi overweight pada anak juga tinggi, yaitu 15.3\% Prevalensi overweight pada anak balita Baduy Luar ini sedikit lebih tinggi dibandingkan dengan prevalensi overweight anak balita Indonesia hasil Riskesdas, yaitu 12.2\%(Depkes, 2008).

Tabel 13. Statistik Status Gizi Balita di Baduy Luar

\begin{tabular}{lcc}
\hline \multicolumn{1}{c}{ Status Gizi } & Z-score & Sd \\
\hline $\mathrm{BB} / \mathrm{U}$ & -1.18 & 1.21 \\
$\mathrm{~TB} / \mathrm{U}$ & -1.65 & 2.88 \\
$\mathrm{BB} / \mathrm{TB}$ & -0.02 & 2.39 \\
\hline
\end{tabular}

Masalah gizi tersebut menunjukkan bahwa anak Baduy menghadapi masalah gizi kronis dan juga akut. Tidak hanya itu, anak-anak Ba- duy Luar ini juga mengalami masalah gizi ganda (double-burden). Kalau dilihat dari nilai Zscore (Tabel 13), anak Baduy rata-rata mempunyai Z-score BB/ U -1. 18 dan TB/ U -1.65.

\section{Status Gizi Baduy Dalam}

Adat Baduy Dalam tidak mengijinkan peneliti (atau penduduk luar Baduy) menimbang atau mengukur status gizi secara antropometri. Oleh karena itu kami tidak memperoleh data status gizi orang tua dan anak di Baduy Dalam. Tidak hanya itu, karena topografi yang berbukit dan tidak rata, serta rumah yang terbuat dari bamboo (lantai dan dinding) dengan atap yang rendah, maka untuk mencari tempat yang rata untuk meletakkan timbangan berat badan dan alat ukur tinggi badan (microtoise) juga sangat tidak mungkin dilakukan.

Berdasarkan pengamatan terhadap orang tua di Baduy Dalam, perawakan orangtua tergolong kecil, tidak jauh berbeda dengan orang tua di Baduy Luar. Anak-anak mereka juga kecil, seperti anak-anak di Baduy Luar.

\section{Status Gizi Orang Dewasa Baduy Muslim}

Rata-rata umur suami dan istri responden Baduy Muslim masih tergolong muda, masing-masing 31 tahun dan 26 tahun (Tabel 14) atau umur suami 5 tahun lebih tua dari umur istri. Berat badan suami dan istri masing-masing $50 \mathrm{~kg}$ dan $50 \mathrm{~kg}$, sedangkan tinggi badan $155 \mathrm{~cm}$ dan istri $149 \mathrm{~cm}$. Dengan pola berat badan dan tinggi badan tersebut jelas orang Baduy Muslim berperawakan hampir sama dengan orang Baduy Luar.

Tabel 14. Statistik Umur dan Antropometri suami dan Istri di Baduy Muslim

\begin{tabular}{lcc}
\hline Karakteristik & Suami & Istri \\
\hline Umur (tahun) & $31.2 \pm 6.6$ & $26.2 \pm 4.7$ \\
Berat Badan $(\mathrm{kg})$ & $50.0 \pm 8.6$ & $50.5 \pm 10.3$ \\
Tinggi Badan $(\mathrm{cm})$ & $155.5 \pm 6.9$ & $149.4 \pm 4.7$ \\
IMT & $20.6 \pm 2.1$ & $22.6 \pm 4.4$ \\
\hline
\end{tabular}

Kalau dilihat indeks massa tubuh (BMI), suami mempunyai BMI (20.6) lebih rendah dibandingkan dengan BMI istri (22.6). Ibu-ibu cenderung berperawakan lebih gemuk. Berdasarkan BMI rata-rata, orang dewasa Baduy Muslim tergolong normal.

Pada Tabel 15 terlihat bahwa semua orang dewasa laki-laki Baduy Muslim tergolong normal; sedangkan pada orang dewasa perempuan 10\% tergolong kurus (wasted) dan 30\% tergolong overweight. Keadaan ini menunjukkan adanya masalah gizi gandapada ibu-ibu di Baduy Muslim. 
Tabel 15. Sebaran Suami atau Istri menurut Status Gizi (IMT) di Baduy Muslim

\begin{tabular}{lcccc}
\hline \multirow{2}{*}{ IMT } & \multicolumn{2}{c}{ Suami } & \multicolumn{2}{c}{ Istri } \\
\cline { 2 - 5 } & $\mathbf{n}$ & $\%$ & $\mathbf{n}$ & $\%$ \\
\hline$<18.5$ & 0 & 0.0 & 4 & 10.0 \\
$18.5-25.0$ & 5 & 100.0 & 12 & 60.0 \\
$>25$ & 0 & 0.0 & 6 & 30.0 \\
\hline
\end{tabular}

\section{Status Gizi Anak Balita Baduy Muslim}

Berdasarkan hasil perhitungan Z-skor $\mathrm{BB} / \mathrm{U}$ dan dengan menggunakan titik batas <2SD sebagai underweight, maka prevalensi underweight pada anak balita di Baduy Muslim adalah 9.5\% (Tabel 16). Prevalensi underweight anak Baduy Muslim jauh lebih rendah dibandingkan prevalensi anak Indonesia hasil Riset Kesehatan Dasar (Riskesdas) 2007, yaitu $18.4 \%$

Tabel 16. Persentase Status Gizi Balita di Baduy Muslim menurut Kategori Z-score

\begin{tabular}{|c|c|c|c|}
\hline Status Gizi & Z-score $<-2$ & $-2<$ Z-core $<+2$ & Z-score > +2 \\
\hline $\mathrm{BB} / \mathrm{U}$ & 9.5 & 90.5 & 0.0 \\
\hline$T B / U$ & 50.0 & 50.0 & 0.0 \\
\hline $\mathrm{BB} / \mathrm{TB}$ & 11.1 & 66.7 & 22.2 \\
\hline
\end{tabular}

Prevalensi stunted (pendek) secara keseluruhan adalah sebesar $50.0 \%$ Prevalensi ini jauh lebih tinggi daripada gambaran prevalensi stunting di Indonesia hasil Riskesdas 2007, yang hanya sekitar $36.8 \%$ Artinya kondisi ini mencerminkan tingkat kesejahteraan masyarakat Baduy Muslim masih rendah.

Berdasarkan hasil perhitungan Z-skor indeks BB/TB dengan kriteria wasted < - 2 SD, maka ditemukan prevalensi wasted sebesar $11.1 \%$ (Tabel 16). Prevalensi wasted ini sedikit lebih rendah dibandingkan dengan prevalensi wasted anak balita hasil Riskesdas 2007 di Indonesia, yaitu $13,6 \%$ Prevalensi overweight pada anak juga tinggi, yaitu $15.3 \%$ Masalah gizi tersebut menunjukkan bahwa anak Baduy menghadapi masalah gizi kronis.

Kalau dilihat dari nilai Z-score pada Tabel 17 terlihat bahwa nilai Z-score BB/U, TB/ U dan BB/TB masing-masing -0.8, -2.2 dan 0.5 . Hal ini juga menunjukkan bahwa status gizi anak balita tergolong normal berdasarkan Zscore $\mathrm{BB} / \mathrm{U}$ dan $\mathrm{BB} / \mathrm{TB}$, tetapi tergolong stunting (-2.2) berdasarkan Z-score TB/ $\mathrm{U}$.

Tabel 17. Statistik Status Gizi Balita di Baduy Muslim

\begin{tabular}{lcc}
\hline \multicolumn{1}{c}{ Status Gizi } & Z-score & Sd \\
\hline $\mathrm{BB} / \mathrm{U}$ & -0.8 & 1.1 \\
$\mathrm{~TB} / \mathrm{U}$ & -2.2 & 1.9 \\
$\mathrm{BB} / \mathrm{TB}$ & 0.5 & 2.8 \\
\hline
\end{tabular}

\section{Faktor-faktor yang Berpengaruh terhadap Status Gizi}

\section{Status Gizi Suami Istri}

Analisis regresi antara status gizi suami atau istri menurut Indeks Massa Tubuh (IMT) dengan dua peubah bebas yang diperkirakan mempengaruhinya hanya dilakukan untuk data Baduy Luar. Untuk Baduy Dalam dan Baduy Muslim analisis ini tidak dilakukan karena keterbatasan data. Peubah bebas yang diduga akan berpengaruh terhadap status gizi tersebut adalah pendapatan dan umur.

Pendapatan dan umur berpengaruh sangat nyata terhadap status gizi suami menurut IMT seperti ditunjukkan oleh Tabel 18. Semakin tinggi pendapatan semakin tinggi IMT, namun sebaliknya semakin tinggi umur atau semakin tua semakin rendah IMT (Tabel 19). Kedua peubah bebas ini hanya mampu menjelaskan sebesar $9.39 \%$ keragaman IMT, sebanyak $5.86 \%$ dij elaskan oleh pendapatan dan sebesar 3.53\% dij elaskan oleh usia seperti dapat dilihat pada Tabel 20. Hal ini mudah dipahami karena

Tabel 18. Analisis Ragam Model Regresi antara IMT Suami sebagai Peubah Tak Bebas dengan Pendapatan dan Umur sebagai Peubah Bebas pada Baduy Luar

\begin{tabular}{lccccc}
\hline \multicolumn{1}{c}{ Sumber Keragaman } & $\mathbf{d b}$ & $\mathbf{J ~ K}$ & $\mathbf{K T}$ & $\mathbf{F}_{\text {hit }}$ & Peluang \\
\hline Regresi & 2 & 75.92 & 37.96 & 10.41 & 0.0001 \\
Galat & 201 & 732.99 & 3.65 & & \\
Total & 203 & 808.91 & & & \\
\hline
\end{tabular}

Tabel 19. Persamaan Regresi IMT Suami pada Baduy Luar

\begin{tabular}{lcccc}
\hline \multicolumn{1}{c}{ Peubah Bebas } & $\begin{array}{c}\text { Koefisien } \\
\text { Regresi }\end{array}$ & $\begin{array}{c}\text { Standar } \\
\text { Error }\end{array}$ & F $_{\text {hit }}$ & Peluang \\
\hline Intercept & 21.59454510 & 0.43547660 & 2459.00 & 0.0001 \\
Pendapatan (rp/ kap/ bulan) & 0.00000086 & 0.00000031 & 7.83 & 0.0056 \\
Umur (tahun) & -0.03214308 & 0.00991595 & 10.51 & 0.0014 \\
\hline
\end{tabular}


Tabel 20. Kontribusi Peubah Bebas terhadap IMT Suami pada Baduy Luar

\begin{tabular}{lcccc}
\hline \multicolumn{1}{c}{ Peubah Bebas } & $\mathbf{R}^{2}$ parsial & $\mathbf{R}^{2}$ Model & $\mathbf{F}_{\text {hit }}$ & Peluang \\
\hline Pendapatan (rp/kap/bulan) & 0.0586 & 0.0586 & 12.5660 & 0.0005 \\
Umur (tahun) & 0.0353 & 0.0939 & 7.8274 & 0.0005 \\
\hline
\end{tabular}

semakin tinggi pendapatan akan meningkatkan kemampuan menyediakan pangan sehingga memungkinkan untuk mengonsumsi pangan lebih banyak sehingga berat badan meningkat yang pada akhirnya IMT meningkat. Namun sebaliknya semakin tua umur suami semakin kecil nilai IMT. Hal ini dapat terjadi karena peningkatan umur biasanya diikuti penurunan berat badan sehingga akhirnya nilai IMT turun.

Pendapatan dan umur berpengaruh sangat nyata terhadap status gizi istri menurut IMT seperti ditunjukkan oleh Tabel 21. Semakin tinggi pendapatan semakin tinggi IMT, namun sebaliknya semakin tinggi umur atau semakin tua semakin rendah IMT seperti ditunjukkan oleh Tabel 22. Kedua peubah bebas ini hanya mampu menjelaskan sebesar $9.49 \%$ keragaman IMT, sebanyak $5.89 \%$ dijelaskan oleh pendapatan dan sebesar 3.61\% dij elaskan oleh usia seperti dapat dilihat pada Tabel 23. Hal ini mudah dipahami karena semakin tinggi pendapatan akan meningkatkan kemampuan menyediakan pangan sehingga memungkinkan untuk mengkonsumsi pangan lebih banyak akhirnya berat badan meningkat yang pada akhirnya IMT meningkat. Namun sebaliknya semakin tua umur suami semakin kecil nilai IMT. Hal ini dapat terjadi karena peningkatan umur biasanya diikuti penurunan berat badan sehingga akhirnya nilai IMT turun. Tampak bahwa persamaan regresi IMT suami dan istri hampir serupa.

\section{Faktor-faktor yang berhubungan dengan status gizi balita}

Analisis faktor-faktor yang berhubungan dengan status gizi balita hanya dilakukan untuk data Baduy Luar dan Baduy Muslim. Analisis ini tidak dapat dilakukan untuk Baduy Dalam karena keterbatasan data. Orang Baduy Dalam sangat sulit untuk memberikan kesempatan kepada peneliti untuk mengukur berat dan tinggi badan balitanya.

Pada Baduy Luar faktor-faktor yang berhubungan secara nyata dengan status gizi adalah umur balita, jumlah anggota rumah tangga, pendapatan, pengetahuan gizi, dan kemampuan membaca istri seperti dapat dilihat pada Tabel 24. Pada Baduy Muslim hanya umur dan pendapatan yang berhubungan dengan status gizi balita. Hal ini terjadi mungkin karena peubah besarnya banyaknya anggota rumah tangga, pendidikan gizi dan kemampuan membaca istri sudah tidak sensitif lagi terhadap status gizi anak karena seperti pengetahuan gizi ataupun kemampuan membaca pada Baduy Muslim sudah cukup baik, sementara pada Baduy Dalam peningkatan pengetahuan gizi atau kemampuan membaca akan sensitif terhadap peningkatan status gizi balita.

Pada Baduy Luar semakin tinggi umur balita semakin rendah status gizi menurut $\mathrm{BB} /$ $\mathrm{U}$ atau BB/TB. Hal ini berarti bahwa balita yang lebih muda status gizinya lebih baik.

Tabel 21. Analisis Ragam Model Regresi antara IMT Istri sebagai Peubah Tak Bebas dengan Pendapatan dan Umur sebagai Peubah Bebas pada Baduy Luar

\begin{tabular}{lccccc}
\hline \multicolumn{1}{c}{ Sumber Keragaman } & db & J K & KT & F $_{\text {hit }}$ & Peluang \\
\hline Regresi & 2 & 202.12 & 101.06 & 10.44 & 0.0001 \\
Galat & 199 & 1926.97 & 9.68 & & \\
Total & 201 & 2129.09 & & & \\
\hline
\end{tabular}

Tabel 22. Persamaan Regresi IMT Istri pada Baduy Luar

\begin{tabular}{lcccc}
\hline \multicolumn{1}{c}{ Peubah Bebas } & $\begin{array}{c}\text { Koefisien } \\
\text { Regresi }\end{array}$ & $\begin{array}{c}\text { Standar } \\
\text { Error }\end{array}$ & F $_{\text {hit }}$ & Peluang \\
\hline Intercept & 22.79332520 & 0.74422848 & 938.00 & 0.0001 \\
Pendapatan (rp/ kap/ bulan) & 0.00000121 & 0.00000043 & 7.93 & 0.0054 \\
Umur (tahun) & -0.05724416 & 0.01795021 & 10.17 & 0.0017 \\
\hline
\end{tabular}

Tabel 23. Kontribusi Peubah Bebas terhadap IMT Istri pada Baduy Luar

\begin{tabular}{lcccc}
\hline \multicolumn{1}{c}{ Peubah Bebas } & $\mathbf{R}^{2}$ Parsial & $\mathbf{R}^{2}$ Model & $\mathbf{F}_{\text {hit }}$ & Peluang \\
\hline Pendapatan (rp/ kap/ bulan) & 0.0589 & 0.0589 & 12.5109 & 0.0005 \\
Umur (tahun) & 0.0361 & 0.0949 & 7.9291 & 0.0054
\end{tabular}


Tabel 24. Korelasi antara Status Gizi Balita dengan Beberapa Variabel

\begin{tabular}{llcccc}
\hline \multirow{2}{*}{ Variabel } & \multirow{2}{*}{ Status Gizi } & \multicolumn{2}{c}{ Baduy Luar } & \multicolumn{2}{c}{ Baduy Muslim } \\
\cline { 3 - 6 } & & Korelasi & peluang & Korelasi & peluang \\
\hline \multirow{3}{*}{ Umur (bulan) } & $\mathrm{BB} / \mathrm{U}$ & -0.32 & 0.01 & -0.48 & 0.02 \\
& $\mathrm{~TB} / \mathrm{U}$ & -0.13 & 0.29 & 0.28 & 0.25 \\
& $\mathrm{BB} / \mathrm{TB}$ & -0.24 & 0.05 & -0.48 & 0.05 \\
\hline \multirow{3}{*}{ Jumlah anggota rumah tangga } & $\mathrm{BB} / \mathrm{U}$ & 0.12 & 0.32 & -0.02 & 0.91 \\
& $\mathrm{~TB} / \mathrm{U}$ & -0.13 & 0.28 & -0.45 & 0.06 \\
& $\mathrm{BB} / \mathrm{TB}$ & 0.25 & 0.03 & 0.46 & 0.06 \\
\hline \multirow{3}{*}{ Pendapatan (rp/ kapita/ bulan) } & $\mathrm{BB} / \mathrm{U}$ & -0.24 & 0.04 & 0.61 & 0.00 \\
& $\mathrm{~TB} / \mathrm{U}$ & -0.05 & 0.69 & 0.38 & 0.12 \\
& $\mathrm{BB} / \mathrm{TB}$ & -0.18 & 0.13 & -0.44 & 0.06 \\
\hline \multirow{3}{*}{ Pengetahuan gizi } & $\mathrm{BB} / \mathrm{U}$ & 0.16 & 0.17 & 0.19 & 0.40 \\
& $\mathrm{~TB} / \mathrm{U}$ & -0.24 & 0.04 & -0.02 & 0.92 \\
& $\mathrm{BB} / \mathrm{TB}$ & 0.39 & 0.00 & -0.11 & 0.66 \\
\hline \multirow{3}{*}{ Kemampuan membaca istri } & $\mathrm{BB} / \mathrm{U}$ & 0.01 & 0.91 & -0.07 & 0.75 \\
& $\mathrm{~TB} / \mathrm{U}$ & 0.25 & 0.04 & -0.21 & 0.41 \\
\hline
\end{tabular}

J umlah anggota keluarga berpengaruh nyata terhadap status gizi menurut BB/TB. Semakin banyak jumlah anggota keluarga semakin tinggi Z-skor BB/TBnya, hal ini mungkin semakin besar jumlah anggota keluarga semakin banyak yang bekerja sehingga income lebih besar yang pada akhirnya akan meningkatkan status gizi. Makin tinggi pendapatan makin rendah status gizi balita menurut BB/ U. Hal ini nampak tidak logis. Salah satu kemungkinannya adalah apabila anggota rumah tangga sibuk bekerja yang mengakibatkan pendapatan meningkat tetapi anak tidak terurus terutama makan sehingga status gizi anak menurun. Semakin tinggi pengetahuan gizi ibu, semakin tinggi pula status gizi balita menurut $B B / T B$. Semakin tinggi kemampuan membaca istri, semakin tinggi pula status gizi balita menurut TB/ $\mathrm{U}$.

Pada Baduy Muslim hubungan antara umur dengan $\mathrm{BB} / \mathrm{U}$ atau $\mathrm{BB} / \mathrm{TB}$ serupa dengan yang terjadi pada Baduy Luar yaitu semakin tinggi usia semakin rendah Z-skor BB/ $\mathrm{U}$ atau BB/TBnya. Pendapatan berkorelasi sangat nyata dengan status gizi balita menurut Z-skor $\mathrm{BB} / \mathrm{U}$ dengan koefisein korelasi cukup besar yaitu sebesar 0.61 , hal ini berarti bahwa semakin tinggi pendapatan semakin tinggi pula nilai Z-skor BB/ Unya. Hubungan ini berlawanan dengan yang terjadi pada Baduy Luar dan mungkin disebabkan perilaku yang berbeda.

\section{KESIMPULAN}

J enis penyakit kulit yang sering diderita masyarakat Baduy khususnya Baduy Luar adalah penyakit kulit jenis budug. J enis penyakit lain yang juga sering dialami masyarakat Baduy Luar adalah penyakit kulit gatal-gatal, bentol dan kulit kemerahan. Penyebab penyakit ini lebih disebebkan karena lingkungan kurang bersih dan disebabkan oleh gigitan serangga. Kebiasaan orang Baduy Dalam berpakaian juga cukup berpengaruh terhadap jenis penyakit kulit ini. Orang Baduy jarang mengganti pakaian mereka. Pakaian yang dipakai untuk ngahuma (berladang) serta untuk sehari-hari cenderung sama atau tidak diganti. Setelah mandipun mereka tidak berganti pakaian, mereka berganti pakaian hanya sekitar 1 minggu sekali. Keadaan ini dialami oleh bukan hanya kaum laki-laki juga kaum perempuan Baduy. Mereka juga jarang menggunakan pakaian dalam. Hal ini berkaitan dengan larangan adat dalam hal adab berpakaian. Begitu pula anak-anak jarang berganti pakaian.

Status gizi yang dibahas dalam laporan ini didasarkan pada hasil pengukuran berat badan dan tinggi badan, sehingga dianalisis status gizi menggunakan tiga macam indeks, yaitu indeks berat badan menurut umur (BB/U), indeks panjang badan menurut umur (PB/ $\mathrm{U})$, dan indeks berat badan menurut panjang badan (BB/ PB).

Prevalensi stunted (pendek) secara keseluruhan adalah sebesar $60.6 \%$ Prevalensi ini jauh lebih tinggi daripada prevalensi stunting anak balita di Indonesia hasil Riskesdas 2007, yang hanya sekitar 36.8\% (Depkes, 2008). Artinya kondisi ini mencerminkan tingkat kesejahteraan masyarakat di desa penelitian masih rendah. 


\section{DAFTAR PUSTAKA}

Departemen Kesehatan Republik Indonesia. 2008. Laporan Nasional Hasil Riset Kesehatan Dasar 2007. Bagian Penelitian dan Pengembangan Kesehatan, Departemen Kesehatan, RI. J akarta

Gibson R. 1993. Nutritional Assessment, A Laboratory Manual. Oxford University, New York.
Propinsi Banten. 2002. http:// www. banten.go. id/ ? ink =dt|\&id=684 [Mei 2008]

Riyadi H. 1995. Prinsip Penilaian Status Gizi. J urusan Gizi Masyarakat dan Sumberdaya Keluarga. Fakultas Pertanian, Institut Pertanian Bogor, Bogor.

Tarwotjo Ig \& Soekirman. 1987. Status Gizi Anak. Gizi Indonesia (Jurnal Gizi), 12 (1), 7 - 14. 